\title{
Fostering of Mathematical Critical Thinking Ability Using ARCS Model and Students' Motivation
}

\author{
Suherman 1,2, Adib Mustofa Zaman ${ }^{3}$, Farida ${ }^{4}$ \\ ${ }^{1}$ Doctoral School of Education, University of Szeged, Hungary \\ 2,3,4 Mathematics Education Department, Universitas Islam Negeri Raden Intan Lampung, Indonesia \\ suherman@edu.u-szeged.hu1 ${ }^{1}$, adibjunior04@gmail.com $^{2}$, farida@radenintan.ac.id ${ }^{3}$
}

\begin{abstract}
Article History:

Received : 04-01-2021

Revised : 27-01-2021

Accepted : 28-01-2021

Online : :16-04-2021

Keyword:

ARCS Model;

Critical Thinking;

Students' Motivation.

Mathematical critical thinking skills in mathematics learning is an ability that needs to be mastered by every student in order to support students in the learning process. The purpose of this study was to analyzing the influence and interaction of the ARCS model and learning motivation on students' mathematical critical thinking skills. This research is a quasi-experimental design using cluster random sampling as a sampling technique. The data collection technique used an essay test to determine MCT and a questionnaire to see motivation. The data analysis technique used the normality test, homogeneity, and two-way ANOVA. The results have shown that there is an effect of the ARCS learning model on students' mathematical critical thinking ability, there is no influence of learning motivation on mathematical critical thinking skills, and there is no interaction between ARCS model learning and motivation towards mathematical critical thinking ability. Therefore, the ARCS model can be solution to fostering of mathematical critical thinking abilities.
\end{abstract}

doi) Crossref

https://doi.org/10.31764/jtam.v5i1.3798

\section{(c) (1) (2)}

This is an open access article under the CC-BY-SA license

\section{A. INTRODUCTION}

In line with the progress and development of science and technology which is increasingly rapid, especially in education (Al-Zahrani, 2015; Hayward et al., 2015; Komarudin et al., 2020), it is not impossible that technology and learning will further develop and become a scientific discipline that can play a role in problems-solving in the teaching and learning (Reddy \& Panacharoensawad, 2017; Siagan et al., 2019; Y. F. Surya et al., 2020). In regard for students to be active in learning, the purpose of learning is to be able to develop their potential to have religious-spiritual strength, self-control, personality, intelligence, character, and skills (Fallah et al., 2015; Munifah et al., 2019). Studying mathematics has the goal of forming the characteristics of students in analyzing problems to develop their reasoning skills (Barnhart \& van Es, 2015; E. Surya \& Syahputra, 2017; Widyatiningtyas et al., 2015; Yuliani \& Saragih, 2015), such as the ability to think critically, logically, systematically, can think of ideas orally, pictures, maps, diagrams, graphs and others (Komarudin et al., 2020).

In the 21st century, skills were needed to develop of the achievement. Critical thinking for example. The importance critical thinking is the process of making something original (Dumitru, 2019), regarding exploring the dynamic nature of attentional focusing (Toner \& Moran, 2016). Critical thinking is an essential skill that needs to be complemented by a person to compete with the developments and changes in primary-day in the classroom (Alper, 2010; 
Ismail et al., 2018; Ku, 2009)(Alpers, 2010; Ku, 2009). Therefore, the need to apply this skill as early as school level and as part of a student's preparation for the future (Hartinah et al., 2019; Marin \& Halpern, 2011).

The fact was shown that the ability to think mathematically is low including the ability of critical thinking mathematically (Kurniati et al., 2015), and then the critical thinking ability is low in the logical-mathematics classroom (Seventika et al., 2018). Based on field data, 90.90\% of students have difficulty understanding mathematical critical thinking skills. Also, based on interview data with mathematics teachers, students are still less interested in learning mathematics. The monotonous learning atmosphere causes students to feel bored because educators convey mathematical concepts still using conventional methods. The other factor that influence the students' low mathematical critical thinking skills are learning motivation (Cho \& Heron, 2015; Holmes \& Hwang, 2016; Kurniati et al., 2015). Motivation is an important skill in the teaching process. Motivation to learn is encouragement from within and outside of learners who are learning to make some behaviour changes (Tsay et al., 2018; Zepeda et al., 2020), can encourage students to what extend doing success their achievement (Benner et al., 2016; Kraft et al., 2016; Lemberger et al., 2015), and the value as an outcome (Guo et al., 2015; Knievel et al., 2015; Teo \& Milutinovic, 2015).

To tackle the phenomenon of problems in teaching and learning, educators are expected to be able to choose the right learning model to tackle the lack of thinking skills and motivate students in learning mathematics (Firdaus, 2017; Komarudin et al., 2020; S Suherman et al., 2020). The model of Attention, Relevance, Confidence, Satisfaction (ARCS) as the solution in the mathematics teaching process (Li \& Moore, 2018). ARCS model can create learning motivation to improve student learning outcomes (LAÇINBAY \& YILMAZ, 2020; Tseng \& Walsh Jr, 2016; Ying \& Yang, 2013). The ARCS model has a flexible nature so that its implementation it can foster the enthusiasm of students who are less interested in certain subjects. (L.-C. Lee \& Hao, 2015). Then it can train students to learn independently, be responsible, and create self-confidence (Huda et al., 2019; S Suherman et al., 2018).

Based on the previous study, there is found the positive effect in regard ARCS model with the flipped classroom approach (Aşlksoy \& Özdaml, 2016), these studies were concerning with the development of ARCS model integrated flipped classroom approach, additionally there is the limitation that the lower numbers of students have a bias towards this method since it is new. Other previous studies indicate that the ARCS model raises the focus student at the classroom and making positive expectation for achievement (Malik, 2014), and this study was distance learning. Furthermore, the last study was revealed that the students' having satisfaction with achievement from ARCS learning (Li \& Moore, 2018).

Based on the previous article, this research update looks at the influence of both learning models, namely the ARCS model and the conventional model of students' mathematical critical thinking abilities. A more effective learning model will provide a significant increase in mathematical critical thinking abilities. This research was highlighted that mathematical critical concept with ARCS model viewed by students' motivation. Hence, the purpose of the study determine the effect of the ARCS model viewed by students motivation and the interaction between them.

\section{B. METHODS}

This research was Quasi-Experimental Design method. The population was 169 in grade 7 in junior high school in East Lampung. The sampling used by Cluster Random Sampling with a total sample size of 69 students. The respondents were divided into two groups. The first group was the experimental group, namely learning with the ARCS model. The second group was the control group, namely the model used in school. 
The data collection technique was to use an essay test to see the mathematical critical thinking ability and a questionnaire to determine the motivation of students. The instrument was constructed by Cronbach's Alpha and reliability test with Levene statistic. The data analysis technique used the normality test using the Liliefors, the homogeneity test using the Bartlett Test, and the hypothesis test using the two-way ANOVA. The hypothesis are the follow

1. $H_{0 A}$ : There is no influence of the ARCS learning model on mathematical critical thinking abilities

$H_{1 A} \quad$ : There is an effect of the ARCS learning model on mathematical critical thinking abilities

2. $H_{0 B} \quad$ : There is no influence of students' motivation on mathematical critical thinking abilities

$H_{1 B} \quad$ : There is an effect of students' motivation on mathematical critical thinking abilities

3. $H_{0 C} \quad$ : There is no interaction between the ARCS model and students' motivation

$H_{1 C} \quad$ : There is an interaction between the ARCS model and students' motivation

The steps of the ARCS are the follow (Pratama et al., 2019)

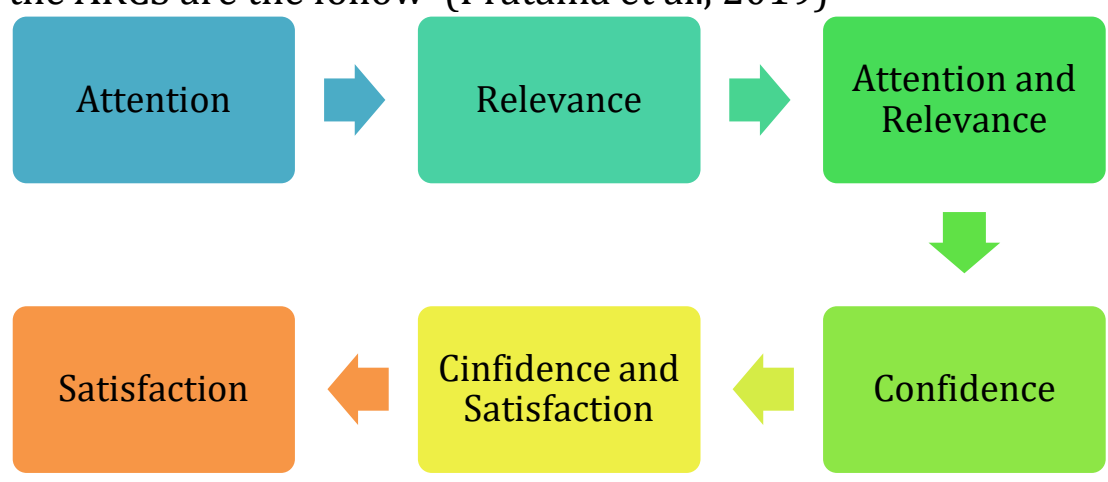

Figure 1. ARCS Steps

Based Figure 1, The teacher reviews the material that students have learned and links the lessons to be discussed. Then in the relevance step, the teacher explains the objectives and benefits of learning and explains the learning material in detail. Furthermore, attention and relevance, the teacher give real examples, and there is a relationship with everyday life. The benefit of providing sample questions is that students find it easier to understand and remember the material. In the confidence step, the teacher guides students in understanding the learning material presented to increase students' confidence in working on the teacher's practice questions. In the confidence and satisfaction track, students are allowed to ask questions, respond to, and work on problems. The last is satisfaction, the teacher provides feedback to stimulate the thinking patterns of students.

The mathematical critical thinking (MCT) was indicated by indicator as follow (H. Lee et al., 2016) 


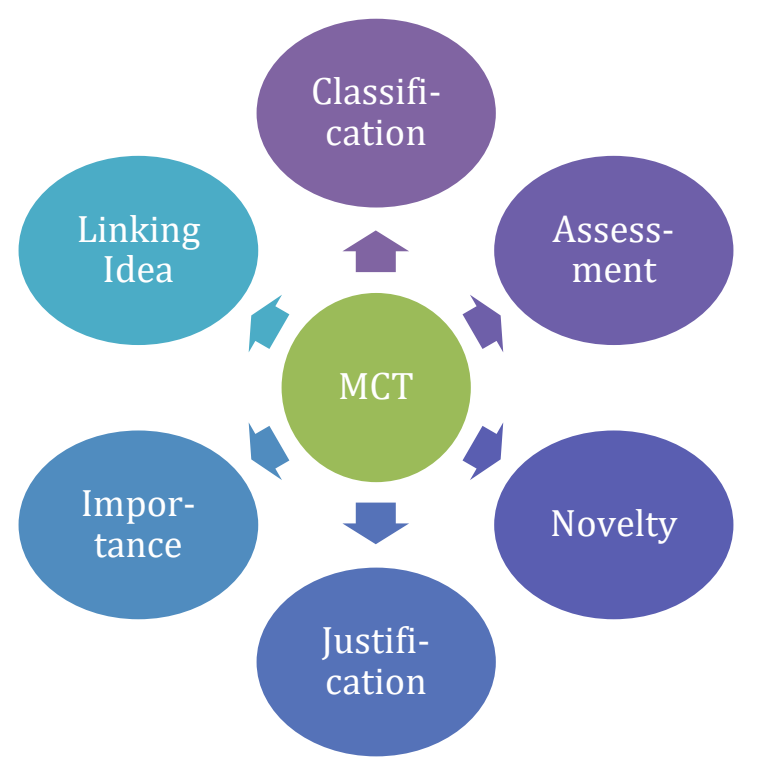

Figure 2. The Indicators of Mathematical Critical Thinking

\section{RESULT AND DISCUSSION}

The instrument test data analysis was loading by Cronbach's Alpha .408 $(p<.05)$ for the reliability and the validity was highest for each question $(p<.05)$. Additionally, the questionnaire was .607 and $(p<.05)$ for reliability and validity respectively. The analysis data for post-test was loading to found the maximum and minimum in experiment and control class. Furthermore, find the central tendency as follow mean, median, mode, range, and deviation standard as following in Table 1

Table 1. Mathematical Critical Thinking Ability Score

\begin{tabular}{cccccccc}
\hline Critical Thinking Ability & Max & Min & Mean & Mode & Median & Range & St. Dev \\
\hline ARCS Model & 100 & 70.91 & 83.63 & 90.91 & 85.45 & 29.09 & 9.19 \\
\hline School Model & 90.91 & 52.73 & 68.41 & 60 & 67.27 & 38.18 & 10.68 \\
\hline
\end{tabular}

Table 1 shows data on student teaching and learning outcomes from different learning model on the ability to think critically. In regard table, it can be seen that the ARCS model is more influencing in increasingly students' critical thinking ability. That is to say that the median and mean values of the ARCS model as experiment class and control class were followed by learning in the school followed. Based on the analysis that the ARCS model not only raises critical thinking but also achievement students' (Afdarni, 2018). Another loading based on motivation was reported by this study. The motivation questionnaire has been scored in Table 2.

Table 2. Motivation Students' Score

\begin{tabular}{cccccccc}
\hline Critical Thinking Ability & Max & Min & Mean & Mode & Median & Range & St. Dev \\
\hline ARCS Model & 129 & 86 & 103.3 & 89 & 101 & 43 & 12.55 \\
\hline School Model & 122 & 80 & 102.2 & 96 & 101 & 42 & 10.50 \\
\hline
\end{tabular}

Based on Table 2, it can be seen that the motivation students' score indifference class is the difference. With the loading rules, it is clear that the mean and deviation standard is the highest scores in the ARCS class then the control class. Concerning the motivation definition that intervention class can support motivation for each student (Jungert et al., 2018). Before reporting the test, it is necessary to construct normality and homogeneity data as a testing 
hypothesis. The normality testing data are displayed in Table 3 and homogeneity loading data are exploring in Table 4.

Table 3. Normality Test on Mathematical Critical Thinking Abilities and Motivation

\begin{tabular}{|c|c|c|c|c|}
\hline Class & Test & Kolmogorov-Smirnov & Sig. & Results \\
\hline Experiment & \multirow{2}{*}{ MCT Test } & .096 & \multirow{3}{*}{$p<.05$} & \multirow{2}{*}{ Normal } \\
\hline Control & & .132 & & \\
\hline $\begin{array}{l}\text { Experiment } \\
\text { Control }\end{array}$ & Questionnaire & $\begin{array}{l}.162 \\
.200\end{array}$ & & Homogeneity \\
\hline
\end{tabular}

Based on Table 3, it can be seen that the ARCS model as experiment class and control class is model followed by school was normally distributed.

Table 4. Homogeneity Test on Mathematical Critical Thinking Abilities and Motivation

\begin{tabular}{|c|c|c|c|c|}
\hline \multirow{2}{*}{ Aspects } & \multicolumn{3}{|c|}{ Student Learning Outcomes } & \multirow[b]{2}{*}{ sig } \\
\hline & Levene Statistic & $\mathbf{d f}_{1}$ & $\mathbf{d f}_{2}$ & \\
\hline MCT & .337 & \multirow{2}{*}{1} & \multirow{2}{*}{69} & $p<.05$ \\
\hline Motivation & .253 & & & \\
\hline
\end{tabular}

In Table 4, we can see that the construct loading data was homogeneity in both aspects of MCT and motivation. The next step were running for the hypothesis. The results data was loading by two-way ANOVA in the table below.

Table 4. The Results of Data Teaching

\begin{tabular}{lrrrrr}
\hline \multicolumn{1}{c}{ Source } & Type III Sum of Squares & df & Mean Square & \multicolumn{1}{c}{ F } & Sig. \\
\hline Corrected Model & $4376.266^{\mathrm{a}}$ & 5 & 875.253 & 8.767 & .000 \\
\hline Intercept & 323090.035 & 1 & 323090.035 & 3236.153 & .000 \\
\hline Motivation & 279.444 & 2 & 139.722 & 1.399 & .254 \\
\hline Model & 3491.676 & 1 & 3491.676 & 34.974 & .000 \\
\hline Motivation*Model & 82.602 & 2 & 41.301 & .414 & .663 \\
\hline Error & 6289.775 & 63 & 99.838 & & \\
\hline Total & 408325.891 & 69 & & & \\
\hline Corrected Total & 10666.040 & 68 & & & \\
\hline $\begin{array}{l}\text { R Squared = .410 (Adjusted R Squared = .363) } \\
\text { Dependent Variable: Mathematical Critical Thinking }\end{array}$
\end{tabular}

Based on table 4, there is a significant difference between the mathematical critical thinking skills of students in the experimental class and the control class. Thus, the treatment of the experimental class and the control class can be applied to measure the extent of the effect of the increase in mathematical critical thinking skills generated after the treatment. It can be seen that for the learning model the result is $p<.05$, so it can be concluded that there is an influence of the ARCS learning model on students' mathematical critical thinking skills. Furthermore, based on the motivation construct loading that there is no effect between motivation and MCT ( $p=.254>.05)$. Additionally, there is no interaction between motivation and ARCS model through MCT ( $p=.663>.05)$.

The ARCS Model can make students 'motivation in understanding learning materials (Kurt \& Keçik, 2017; Milman \& Wessmiller, 2016), prioritizing students' attention and adjusting learning materials so as to foster student self-confidence and change student satisfaction (Ampountolas et al., 2019; Geiger et al., 2017). 
The motivational principles compiled in the ARCS learning process consist of Attention, Relevance, Confidence, and Satisfaction. Educators are expected to teach students to be able to grow, improve, and maintain learning motivation. For Students who are motivated to follow the learning process well, the knowledge and thinking power of students will increase (Asfar \& Asfar, 2020; Ulandari et al., 2019). Mathematical critical thinking in this research was increasingly by the ARCS model. Regarding the ARCS steps that there are many stages that improving students. These steps can be improving mathematical critical thinking skills by providing basic explanations. This step explains the objectives and benefits of learning in detail. So, it can foster the interest and attention of students. In contrast, there are no steps in the control class. This step is following previous research that can build basic skills in critical thinking (Kurt \& Keçik, 2017).

Additionally, the ARCS model can improve mathematical creative thinking ability was because there are steps for confidence and satisfaction. These steps can students' making conclusion about every performance in the class. In other words, feedback by the educator can make students' build self-confidence and report the material in detail. The results were contrast with the previous study that The ARCS model can raise students' motivation (Alhazbi, 2015; Reynolds et al., 2017; Turel \& Sanal, 2018). This means that there is a finding that the ARCS model has no effect on student' motivation.

Based on several previous studies, it appears that there are differences in the treatment of the ARCS model with the conventional learning model (Zhang, 2017). This is because the ARCS model can make students more active in the learning process (Keller, 2016), students are trained to be able to solve problems well (Novotná et al., 2014), the knowledge gained by students will take longer to remember, and this learning model is very effective because it is a learning center that prioritizes the role of students and is student-centered. Hence, the ARCS model can be solution to the lack of mathematical critical thinking.

\section{CONCLUSION AND SUGGESTIONS}

Based on the data analysis and hypothesis testing, the conclusion is: mathematical critical thinking abilities get better with the ARCS model than mathematical critical thinking abilities that use the school model. The student motivation did not influence mathematical critical thinking, and both model and students' motivation not influence mathematical critical thinking. The limitation of this research was focused on grade 7 and the minimum number of samples used. Another thing that there is no feedback in the learning activity and cooperative reciprocity is not controlled, which might be mixed with other exogenous factors (e.g., learning environment and student's previous knowledge), and that is as highlighted researcher in the future.

\section{ACKNOWLEDGEMENT}

We sincerely thank MTs. Ma'arif NU 5 Sekampung, East Lampung, Indonesia for the data. Our acknowledgement is also given to Universitas Islam Negeri Raden Intan Lampung who has supported us with support to continue publishing.

\section{REFERENCES}

Afdarni, V. (2018). Validity Of Learning Devices Based On ARCS Model To Improve Mathematical Critical Thinking Ability. 2nd International Conference on Mathematics and Mathematics Education 2018 (ICM2E 2018).

Alhazbi, S. (2015). ARCS-based tactics to improve students' motivation in computer programming course. 2015 10th International Conference on Computer Science \& Education (ICCSE), 317-321. 
Alper, A. (2010). Critical thinking disposition of pre-service teachers. Egitim ve Bilim, 35(158), 14.

Al-Zahrani, A. M. (2015). From passive to active: The impact of the flipped classroom through social learning platforms on higher education students' creative thinking. British Journal of Educational Technology, 46(6), 1133-1148.

Ampountolas, A., Shaw, G., \& James, S. (2019). Active learning to improve self-confidence and decision-making skills through the use of hotel simulation. Journal of Hospitality \& Tourism Education, 31(3), 125-138.

Asfar, A. M. I. T., \& Asfar, A. M. I. A. (2020). Learning Design Based on Local Wisdom Maddawadawa, Mammanu-manu and Mappettuada. JTAM Uurnal Teori Dan Aplikasi Matematika), 4(2), 214-223.

Așıksoy, G., \& Özdamlı, F. (2016). Flipped Classroom adapted to the ARCS Model of Motivation and applied to a Physics Course. Eurasia Journal of Mathematics, Science and Technology Education, 12(6), 1589-1603.

Barnhart, T., \& van Es, E. (2015). Studying teacher noticing: Examining the relationship among pre-service science teachers' ability to attend, analyze and respond to student thinking. Teaching and Teacher Education, 45, 83-93.

Benner, A. D., Boyle, A. E., \& Sadler, S. (2016). Parental involvement and adolescents' educational success: The roles of prior achievement and socioeconomic status. Journal of Youth and Adolescence, 45(6), 1053-1064.

Cho, M.-H., \& Heron, M. L. (2015). Self-regulated learning: The role of motivation, emotion, and use of learning strategies in students' learning experiences in a self-paced online mathematics course. Distance Education, 36(1), 80-99.

Dumitru, D. (2019). Creating meaning. The importance of Arts, Humanities and Culture for critical thinking development. Studies in Higher Education, 44(5), 870-879.

Fallah, V., Khosroabadi, S., \& Usefi, H. (2015). Development of emotional quotient and spiritual quotient: The strategy of ethics development. International Letters of Social and Humanistic Sciences, 49, 43-52.

Firdaus, F. M. (2017). Improving Primary Students' Mathematical Literacy through Problem Based Learning and Direct Instruction. Educational Research and Reviews, 12(4), 212219.

Geiger, J. M., Cheung, J. R., Hanrahan, J. E., Lietz, C. A., \& Carpenter, B. M. (2017). Increasing competency, self-confidence, and connectedness among foster care alumni entering a 4-year university: Findings from an early-start program. Journal of Social Service Research, 43(5), 566-579.

Guo, J., Marsh, H. W., Parker, P. D., Morin, A. J., \& Yeung, A. S. (2015). Expectancy-value in mathematics, gender and socioeconomic background as predictors of achievement and aspirations: A multi-cohort study. Learning and Individual Differences, 37, 161-168.

Hartinah, S., Suherman, S., Syazali, M., Efendi, H., Junaidi, R., Jermsittiparsert, K., \& Umam, R. (2019). Probing-prompting based on ethnomathematics learning model: The effect on mathematical communication skill. Journal for the Education of Gifted Young Scientists, $7(4), 799-814$.

Hayward, M. D., Hummer, R. A., \& Sasson, I. (2015). Trends and group differences in the association between educational attainment and US adult mortality: Implications for understanding education's causal influence. Social Science \& Medicine, 127, 8-18.

Holmes, V.-L., \& Hwang, Y. (2016). Exploring the effects of project-based learning in secondary mathematics education. The Journal of Educational Research, 109(5), 449-463.

Huda, S., Rinaldi, A., Suherman, S., Sugiharta, I., Astuti, D. W., Fatimah, O., \& Prasetiyo, A. E. (2019). Understanding of Mathematical Concepts in the Linear Equation with Two 
Variables: Impact of E-Learning and Blended Learning Using Google Classroom. AlJabar: Jurnal Pendidikan Matematika, 10(2), 261-270.

Ismail, N. S., Harun, J., Zakaria, M. A. Z. M., \& Salleh, S. M. (2018). The effect of Mobile problembased learning application DicScience PBL on students' critical thinking. Thinking Skills and Creativity, 28, 177-195.

Jungert, T., Van den Broeck, A., Schreurs, B., \& Osterman, U. (2018). How colleagues can support each other's needs and motivation: An intervention on employee work motivation. Applied Psychology, 67(1), 3-29.

Keller, J. M. (2016). Motivation, learning, and technology: Applying the ARCS-V motivation model. Participatory Educational Research, 3(2), 1-15.

Knievel, I., Lindmeier, A. M., \& Heinze, A. (2015). Beyond knowledge: Measuring primary teachers' subject-specific competences in and for teaching mathematics with items based on video vignettes. International Journal of Science and Mathematics Education, 13(2), 309-329.

Komarudin, K., Suherman, S., Puspita, L., Arrafiansyah, R., \& Hasanah, U. (2020). Program course lab 2.4 mathematics learning media for increasing of creativity domain at Higher Order Thinking Skills (HOTS). Journal of Gifted Education and Creativity, 7(3), 131-136.

Komarudin, Pranata, D., Nurhasanah, U., \& Suherman. (2020). Developing Islamic-Friendly Android Mobile Apps for Understanding Mathematical Concepts. 1st Raden Intan International Conference on Muslim Societies and Social Sciences (RIICMuSSS 2019), 110-117.

Kraft, M. A., Marinell, W. H., \& Shen-Wei Yee, D. (2016). School organizational contexts, teacher turnover, and student achievement: Evidence from panel data. American Educational Research Journal, 53(5), 1411-1449.

$\mathrm{Ku}, \mathrm{K} . \mathrm{Y}$. (2009). Assessing students' critical thinking performance: Urging for measurements using multi-response format. Thinking Skills and Creativity, 4(1), 70-76.

Kurniati, K., Kusumah, Y. S., Sabandar, J., \& Herman, T. (2015). Mathematical critical thinking ability through contextual teaching and learning approach. Journal on Mathematics Education, 6(1), 53-62.

Kurt, P. Y., \& Keçik, İ. (2017). The effects of arcs motivational model on student motivation to learn English. European Journal of Foreign Language Teaching.

LAÇİNBAY, K., \& YILMAZ, M. (2020). Görsel Sanatlar Ders Materyali Geliștirme Sürecinde ARCS Motivasyon Modelinin Kullanımı. Kastamonu Ĕ̆itim Dergisi, 28(1), 468-481.

Lee, H., Parsons, D., Kwon, G., Kim, J., Petrova, K., Jeong, E., \& Ryu, H. (2016). Cooperation begins: Encouraging critical thinking skills through cooperative reciprocity using a mobile learning game. Computers \& Education, 97, 97-115.

Lee, L.-C., \& Hao, K.-C. (2015). Designing and Evaluating Digital Game-Based Learning with the ARCS Motivation Model, Humor, and Animation: International Journal of Technology and Human Interaction, 11(2), 80-95. https://doi.org/10.4018/ijthi.2015040105

Lemberger, M. E., Selig, J. P., Bowers, H., \& Rogers, J. E. (2015). Effects of the Student Success Skills program on executive functioning skills, feelings of connectedness, and academic achievement in a predominantly Hispanic, low-income middle school district. Journal of Counseling \& Development, 93(1), 25-37.

Li, K., \& Moore, D. R. (2018). Motivating students in massive open online courses (MOOCs) using the attention, relevance, confidence, satisfaction (arcs) model. Journal of Formative Design in Learning, 2(2), 102-113.

Malik, S. (2014). Effectiveness of ARCS Model of Motivational Design to Overcome Non Completion Rate of Students in Distance Education. Turkish Online Journal of Distance Education, 15(2), 194-200. 
Marin, L. M., \& Halpern, D. F. (2011). Pedagogy for developing critical thinking in adolescents: Explicit instruction produces greatest gains. Thinking Skills and Creativity, 6(1), 1-13.

Milman, N. B., \& Wessmiller, J. (2016). Motivating the online learner using Keller's ARCS model. Distance Learning, 13(2), 67.

Munifah, M., Syamsul, H., Ulfi Dina, H., Subandi, S., Muhamad, S., \& Rofiqul, U. (2019). The Use of Management Strategies to Attract the Public's Interest in Pesantren: A New Model for Pesantren Dynamics Study. International Journal of Innovation, Creativity and Change, 8(8), 263-283.

Novotná, J., Eisenmann, P., Přibyl, J., Ondrušová, J., \& Břehovský, J. (2014). Problem solving in school mathematics based on heuristic strategies. Journal on Efficiency and Responsibility in Education and Science, 7(1), 1-6.

Pratama, R. W., Sudiyanto, \& Riyadi. (2019). The Development Of Attention, Relevance, Confidence, And Satisfaction (ARCS) Model Based on Active Learning to Improve Students'learning Motivation. Al-Jabar: Jurnal Pendidikan Matematika, 10(1), 59-66.

Reddy, M., \& Panacharoensawad, B. (2017). Students Problem-Solving Difficulties and Implications in Physics: An Empirical Study on Influencing Factors. Journal of Education and Practice, 8(14), 59-62.

Reynolds, K. M., Roberts, L. M., \& Hauck, J. (2017). Exploring motivation: Integrating the ARCS model with instruction. Reference Services Review.

Seventika, S. Y., Sukestiyarno, Y. L., \& Mariani, S. (2018). Critical thinking analysis based on Facione (2015)-Angelo (1995) logical mathematics material of vocational high school (VHS). Journal of Physics: Conference Series, 983(1), 012067.

Siagan, M. V., Saragih, S., \& Sinaga, B. (2019). Development of Learning Materials Oriented on Problem-Based Learning Model to Improve Students' Mathematical Problem Solving Ability and Metacognition Ability. International Electronic Journal of Mathematics Education, 14(2), 331-340.

Suherman, S, Komarudin, K., Rosyid, A., Aryanita, S., Asriyanto, D., Aradika Putra, T., \& Anggoro, T. (2018). Improving Trigonometry Concept Through STEM (Science, Technology, Engineering, And Mathematics) Learning. International Conference On Multidisciplinary Academic (ICMA), Indonesia.

Suherman, S, Prananda, M. R., Proboningrum, D. I., Pratama, E. R., \& Laksono, P. (2020). Improving higher order thinking skills (hots) with project based learning (pjbl) model assisted by geogebra. Journal of Physics: Conference Series, 1467(1), 012027.

Surya, E., \& Syahputra, E. (2017). Improving High-Level Thinking Skills by Development of Learning PBL Approach on the Learning Mathematics for Senior High School Students. International Education Studies, 10(8), 12-20.

Surya, Y. F., Marta, R., \& Wijaya, T. T. (2020). Measurement of mathematics problems solving ability using problem based mathematics question. Journal of Physics: Conference Series, 1613(1), 012026.

Teo, T., \& Milutinovic, V. (2015). Modelling the intention to use technology for teaching mathematics among pre-service teachers in Serbia. Australasian Journal of Educational Technology, 31(4).

Toner, J., \& Moran, A. (2016). On the importance of critical thinking: A response to Wulf's (2015) commentary. Psychology of Sport and Exercise, 22, 339-340.

Tsay, C. H.-H., Kofinas, A., \& Luo, J. (2018). Enhancing student learning experience with technology-mediated gamification: An empirical study. Computers \& Education, 121, 117.

Tseng, H. W., \& Walsh Jr, E. J. (2016). Blended vs. Traditional course delivery: Comparing students' motivation, learning outcomes, and preferences. Quarterly Review of Distance Education, 17(1). 
Turel, Y. K., \& Sanal, S. O. (2018). The effects of an ARCS based e-book on student's achievement, motivation and anxiety. Computers \& Education, 127, 130-140.

Ulandari, L., Amry, Z., \& Saragih, S. (2019). Development of Learning Materials Based on Realistic Mathematics Education Approach to Improve Students' Mathematical Problem Solving Ability and Self-Efficacy. International Electronic Journal of Mathematics Education, 14(2), 375-383.

Widyatiningtyas, R., Kusumah, Y. S., Sumarmo, U., \& Sabandar, J. (2015). The Impact of Problem-Based Learning Approach to Senior High School Students' Mathematics Critical Thinking Ability. Indonesian Mathematical Society Journal on Mathematics Education, 6(2), 30-38.

Ying, M.-H., \& Yang, K.-T. (2013). A Game-based Learning System using the ARCS Model and Fuzzy Logic. JSW, 8(9), 2155-2162.

Yuliani, K., \& Saragih, S. (2015). The Development of Learning Devices Based Guided Discovery Model to Improve Understanding Concept and Critical Thinking Mathematically Ability of Students at Islamic Junior High School of Medan. Journal of Education and Practice, 6(24), 116-128.

Zepeda, C. D., Martin, R. S., \& Butler, A. C. (2020). Motivational strategies to engage learners in desirable difficulties. Journal of Applied Research in Memory and Cognition, 9(4), 468474.

Zhang, W. (2017). Design a civil engineering micro-lecture platform based on the ARCS model perspective. International Journal of Emerging Technologies in Learning (IJET), 12(01), 107-118. 